\title{
Application of water balance model simulation for water resource assessment in upper blue nile of north ethiopia using hec-hms by gis and remote sensing: case of beles river basin
}

\begin{abstract}
Ethiopia is constantly affected by shortage of water for rain-fed agriculture, mainly because of lack of proper water resources utilization and management practices. For efficient use of available surface water resources with balanced attention to maximize economic, social, and environmental benefits, it is necessary to have effective integrated water resources assessments and planning. Beles river basin is one of the most potential river basins in Ethiopia which is the main tributary for Blue Nile River Basin and accounting 14,200 $\mathrm{km}^{2}$. The objectives of this study was to assess the available surface water resources in the Beles River basin, using a surface water balance model simulation by HEC-HMS hydrological modeling system by estimating surface runoff and simulating hydrological processes due to distributed land use, soil, climatological and hydro- metrological condition in the entire river basin. DEM of four tiles (170/52, 170/53, 171/52 and 171/53 path/row) was downloaded from ASTER Global DEM (GDEM) then rectified, corrected and Geo-referenced to the UTM (WSG1984 UTM-37N) projection system of the study area. Then GIS layers that were used as input data for the flow simulation were prepared using Arc GIS 9.3 and used in the HEC-HMS 3.5 calibration of the Beles River sub basin using daily precipitation and flow data from 2003 and 2004 and validated by 2005 and tested statistically by relative error and the residual method. Then the validated surface runoff is used for water balance assessment. Result of mean monthly simulated runoff show that $76 \mathrm{~mm}$ for Gilgel Beles, $55.7 \mathrm{~mm}$ for Upper Beles and $42.4 \mathrm{~mm}$ for Lower Beles. According to the result of water balance assessment; the highest water deficit was observed in 2003 \& 2004 of Lower Beles but 2004 for Gilgel Beles and Upper Beles was observed to be a water surplus year were as 2003 showed the deficit year and there is no significant change in soil moisture storage in Beles River Basin in 2005. In the future, it would be advisable to consider immerging issues in water resource measures like GIS modeling with Remote Sensing data for effective and efficient water resource management when there is limited and lack of data.
\end{abstract}

Keywords: hec-hms, blue nile, gis, beles, remote sensing
Volume I Issue 7 - 2017

\author{
Ashebir Haile Tefera \\ Ethiopian Institute Agricultural Research, Addis Ababa University, \\ Ethiopia
}

\section{Correspondence: Ashebir Haile Tefera, Ethiopian Institute Agricultural Research, Addis Ababa University, Ethiopia,} Email ashu_haile@yahoo.com, haileashebir@gmail.com

Received: August 03, 2017 | Published: December 27, 2017

\section{Introduction}

Ethiopia is commonly referred to as "the water tower of east Africa", because of the huge amount of surface runoff from the Ethiopian highlands that make up over $86 \%$ of the flow of the Nile River. ${ }^{1}$ However, the country is constantly affected by shortage of water for rain-fed agriculture, mainly because of lack of proper water resources utilization and management practices. About 3.8 million ha of the cultivable land area is potentially irrigable but, so far, only about 289,000 ha has been irrigated. ${ }^{2}$ According to, ${ }^{3}$ the total renewable freshwater (mean annual flow) of the country is estimated at 122 billionm $^{3}$, and 54.4 billionm $^{3}$ of surface water and 2.6 billionm $^{3}$ of groundwater could be developed for utilization. Currently less than $5 \%$ of the surface water potential is used for consumptive purposes while groundwater is virtually untouched. The river Nile is one of the longest rivers in the world and the basin area covers approximately $10 \%$ of the African continent. According to the World Bank, ${ }^{4}$ the Nile River Basin is home to an estimated 229 million people in the year 1995 while the basin can be characterized by dramatic increasing of population load, variability and natural resource losses leading to poverty. ${ }^{5}$ Also by climate and land use changes, recurrent droughts may further effect agricultural production and food supply in Ethiopia. ${ }^{6}$ For efficient use of available water resources with balanced attention to maximize economic, social, and environmental benefits, it is necessary to have effective integrated water resources assessments and planning. ${ }^{7}$ The most potential concern of this study is hydrological components which are subsequently changes Beles river basin water balance. Among the water balance components surface water inflow from gauged and un-gauged catchments, precipitation and evaporation pattern and their impact on Beles river basin water balance is not yet studied well. On the other hand, water resource planning and management requires information of inflows from each catchment and total out flow from the entire river basin. There are only few researches available, which well discussed on Beles river water resource management Conway ${ }^{5,8}$ \& Collick et al. ${ }^{9}$ However none of them performed sub-basin stream flow simulation for gauged and ungraded catchment and indicate the available water sources in the 
river basin with aid of integrating remote sensing and GIS application tools using HEC-HMS. Therefore; surface water balance simulation using HEC-HMS model with the help of using remote sensing \& GIS for integrated water resources management may be a better option to fill this gap in the river basin. ${ }^{10}$ Hence, the overall objective of this study is to assess surface hydrological dynamics and evaluate distribution and the available water resource using water balance model which can support planning and decision making process to improve water productivity for sustainable agricultural production in the entire river basin. The specific objectives are:

I. To estimate surface runoff and evapo-transpiration distribution for sustainable water resource utilization in the entire river basin;

II. To simulate hydrological processes using land use, soil, climatological and hydro metrological input parameters and generate data in Beles river basin and

III. To estimate variations due to distributed land use, soil, climatological and hydro-metrological condition in the entire river basin.

\section{Materials and methods}

\section{Description of the study area}

The Beles basin is situated on the Plateau of the north-western highlands and its one of the major tributary of Blue Nile. Its geographic location between from $10^{\circ} 56^{\prime} 00^{\prime \prime}$ to $12^{\circ} 00^{\prime} 00^{\prime \prime} \mathrm{N}$ latitude and $35^{\circ} 15^{\prime} 00^{\prime \prime}$ to $37^{\circ} 00^{\prime} 00^{\prime \prime}$ E longitude (Figure 1) and total area of the basin is about $14,200 \mathrm{Km}^{2}$. The topography of the area is mostly flat with altitudes between $458 \mathrm{~m}$ and $2729 \mathrm{~m}$ above sea level. The Beles basin is one of the most important basins in Ethiopia. It is one of the major sub-basins of upper Blue Nile basin. The recorded mean annual rainfall ranges from $700 \mathrm{~mm}$ to $1800 \mathrm{~mm}$, annual average daily minimum and maximum temperature ranges between $16^{\circ} \mathrm{c}$ and $33^{\circ} \mathrm{c}$ and Annual potential evapo-transpiration is about $1500 \mathrm{~mm}$. The previous studies of the area Conway ${ }^{5,8} \&$ Collick et al. ${ }^{9}$ Showed that the basin has a substantial potential for irrigated and hydropower development. According to the information from Euro consult Mott MacDonald, the total estimated irrigable area in the basin is about 260,000 ha. It represents some $50 \%$ of the total irrigable area in the Abbay (Blue Nile) basin. The area is suitable for growing industrial crops that have considerable export potential. There is also a possibility of groundwater availability in the area. ${ }^{4}$

\section{Data description and processing}

The conceptual framework of this study indicated in the flow chart (Figure 2) starts with collection of hydrological and metrological data. Hydrological data of daily flow discharge was used for model calibration and validation for runoff simulation. Using metrological data total PET was calculated and with rainfall used as input for the model. Combination of Remote Sensing and GIS are the main tools used for terrain processing and watershed delineation in HEC-Geo HMS and digital map is produced as main input for the model. Land cover and soil data were also inputs for the model. Finally, model calibration is made and if its fitness is good model validation is undertaken; otherwise model calibration iteratively continues till the best fit is obtained. The final step of the overall process was a water balance assessment. For this study, ASTER Global DEM (GDEM) from The Ministry of Economy, Trade and Industry of Japan (METI) and the National Aeronautics and Space Administration (NASA) are collaborating on the project to develop ASTER Global Digital Elevation Model (ASTER GDEM), DEM data which are acquired by the satellite-borne sensor "ASTER" to cover all the land of the earth (https://earthexplorer.usgs.gov/) finished with a resolution of 1 arc second ( $30 * 30$ meters position) digital elevation raster that covers almost the entire globe. These facilities allowed downloading a DEM date for the study area (Figure 3) in which four tiles having 170/52, $170 / 53,171 / 52$ and 171/53 path/row was first rectified, corrected and geo-referenced to the UTM (WSG-1984 UTM-37N) projection system.

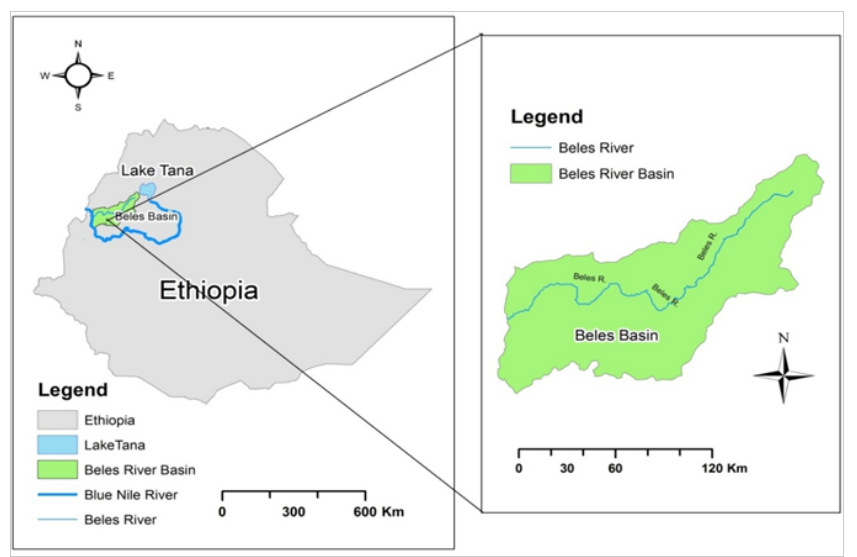

Figure I Location of Beles River basin

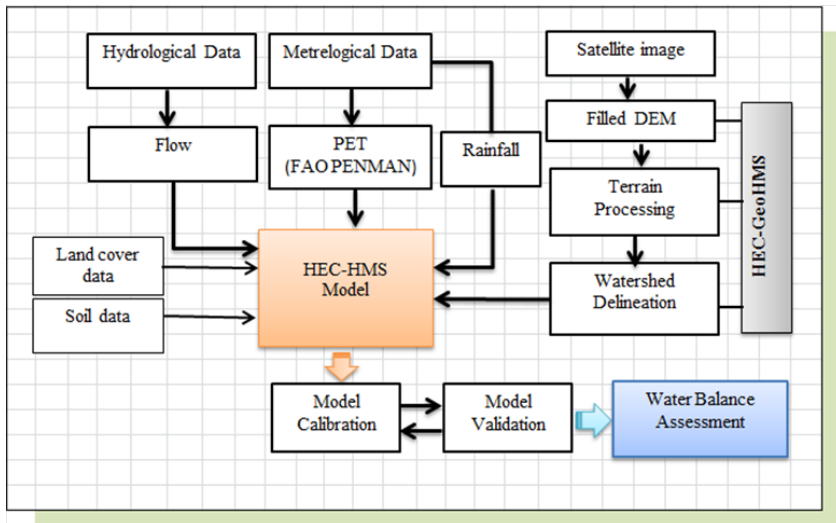

Figure 2 Flow chart showing the input data.

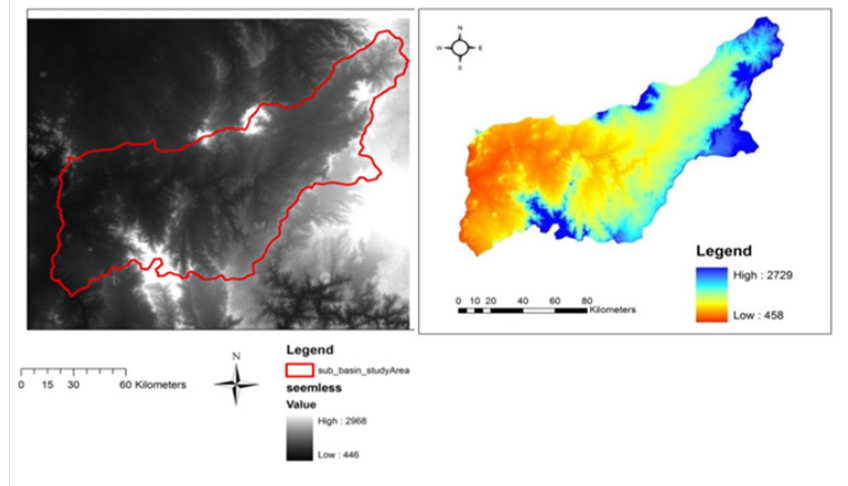

Figure 3 Delineation of river basin from DEM using buffer and elevation model. 


\section{Model calibration and validation}

Calibrating the model was done separately for gauged Beles sub basin. Two years (2003 \& 2004) daily recorded data was taken for calibration. During calibration of the models a simple sensitivity analysis was simply observed to have understanding and simply identifying the most sensitive model parameters which mead the processes easy. This was followed by a manual trial and error procedure until the result of the calibrated model was considered acceptable. But for the model validation, the degree of accuracy of parameter estimates was assessed by applying the model to different data set (2005) which was not used for calibration. Thiemig et al. ${ }^{11}$ defines validation as a process of demonstrating capability of a given site-specific model to make predictions satisfactorily accurate at other site and/or outside the calibration period. Model performance was evaluated by percentage Relative Error (RE) which is expressed by the ratio of the difference of simulated and observed flow to the observed flow as indicated by the following parameter (Equation 1).

Equation 1: Percentage of Relative Error.

$$
\boldsymbol{R E}(\%):=\left(\frac{\text { Simulated }- \text { Observed }}{\text { Obseved flow }}\right) * 100
$$

\section{Water balance model simulation}

Water balance model simulation is the most common method of water assessment in those areas where there is lack of availability data and also the input parameters are very limited to assess water availability in the entire Beles River Basin. ${ }^{12}$ In Beles River Basin there is no surface inflow and irrigation in the 2003 to 2005 inflows and outflows in the system. The major components for water balance assessment of surface storage was included as precipitation (P), Losses (precipitation loss due to Evapo-transpiration (ET), interception, infiltration river outflow $(\mathrm{Q})$ and change in surface storage $(\Delta \mathrm{S})$ as indicated in equation 2 .

Equation 2: Water Balance Model.

$\Delta \mathbf{S}=\mathbf{P}-\mathbf{L o s s e s}($ Evapotranspiration + Infiltration + Interception $)-\mathbf{Q}$

Precipitation and Discharge data in river was acquired from the rain gauge information monitored by the Ethiopian Metrological Agency and form the Ethiopian Ministry of Water Resources of Ethiopia respectively. The assessment was done for each sub basin and the availability of water has been compared.

\section{Results and discussion}

\section{Map of hydrological soil group and vegetation cover}

A hydrological soil group map as shown in the Figure 4 was classified based on the World Reference base for Soil Resources (WRB). ${ }^{13}$ The model developed was used soil data mainly constant rate (infiltration rate) as a major soil data input to simulate surface runoff of with other input. Hence soil group "C" is described as clay loam, shallow sandy loam, soils with low organic matter and usually high in clay content $(1.27-3.81 \mathrm{~mm} / \mathrm{hr}$. of constant rate) and soil group " $\mathrm{D}$ " is described as high swelling properties when wet and heavy plastic clay (constant rate is less than $1.27 \mathrm{~mm} / \mathrm{hr}$.). ${ }^{14}$ From the classification of soil according hydrological soil group more than $60 \%$ of upper Beles soil is "C", Gilgel Beles has more than $76 \%$ but almost majority of lower Beles soils are categorized and " $D$ ". The vegetation cover or the land use/cover was reclassified to generate vegetation cover data for model input as indicated in Figure 5. Hence; mainly seven different land use/land cover features were reclassified such as cultivated land, bushland, grassland, forest/woodland, bamboo, and settlement and rock areas. Extensive vegetation and/or forest cover is not present in the study area. From the result it has been observed that natural vegetation in the lowland part of the study area in general is characterized by a variety of bush/shrubs with woody trees and elephant grass undergrowth and localized bamboo forests. The highland part of the study area is covered by moderately dense eucalyptus trees. Most of the area underlain by a crystalline basement and is apparently unsuitable for agriculture.

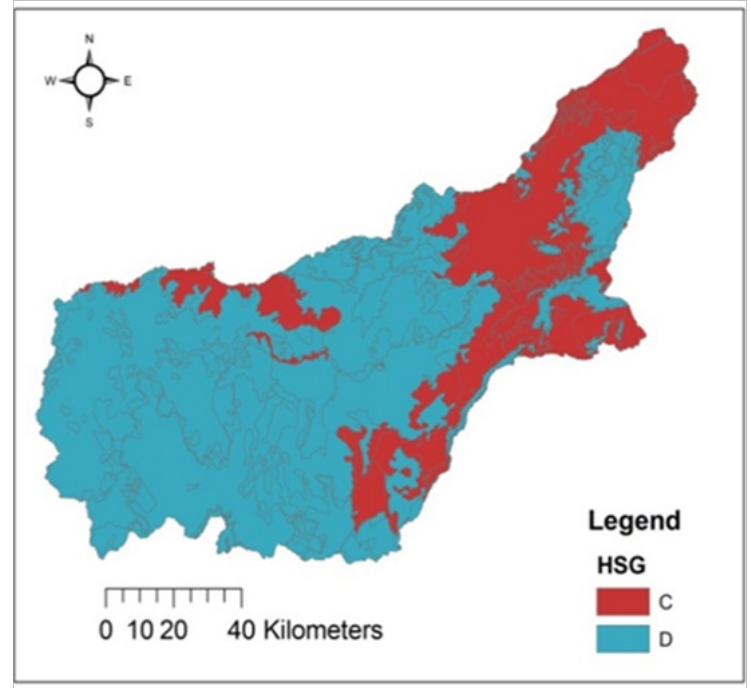

Figure 4 Hydrological soil group map.

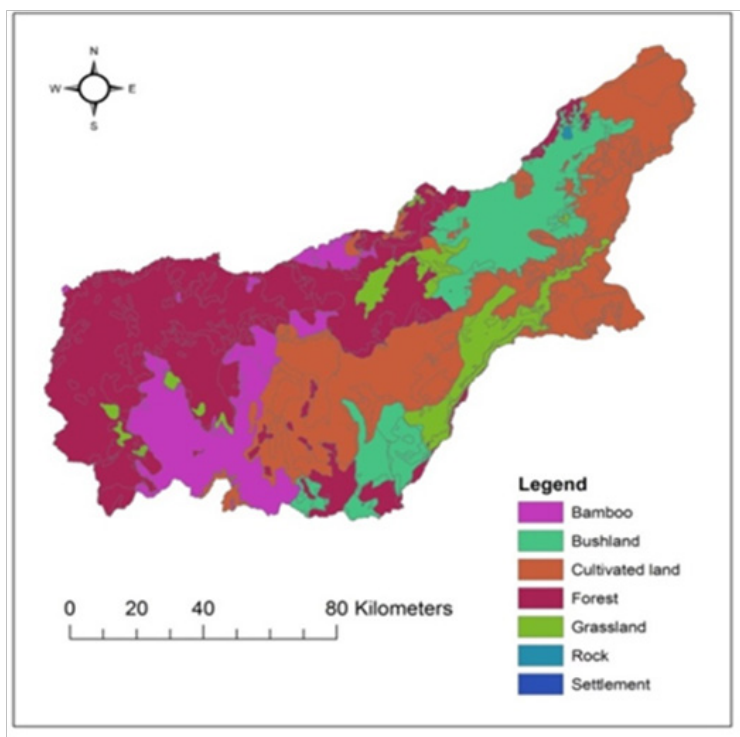

Figure 5 Correlation of land covers of Beles river basin.

\section{Map of basin processing and sub-watershed delineation}

After Basin processing in HEC-GeoHMS three sub basin has been delineated and having the following information and used as a digital map for simulation of runoff in HEC-HMS. The drainage areas are 
$9078.20 \mathrm{~km}^{2}, 3461.80 \mathrm{~km}^{2}$, and $747.11 \mathrm{~km}^{2}$ for the sub watershed Lower, Upper, and Gilgel Beles respectively. The results of the delineation the sub-watershed are indicated in Figure 6 \& Figure 7.

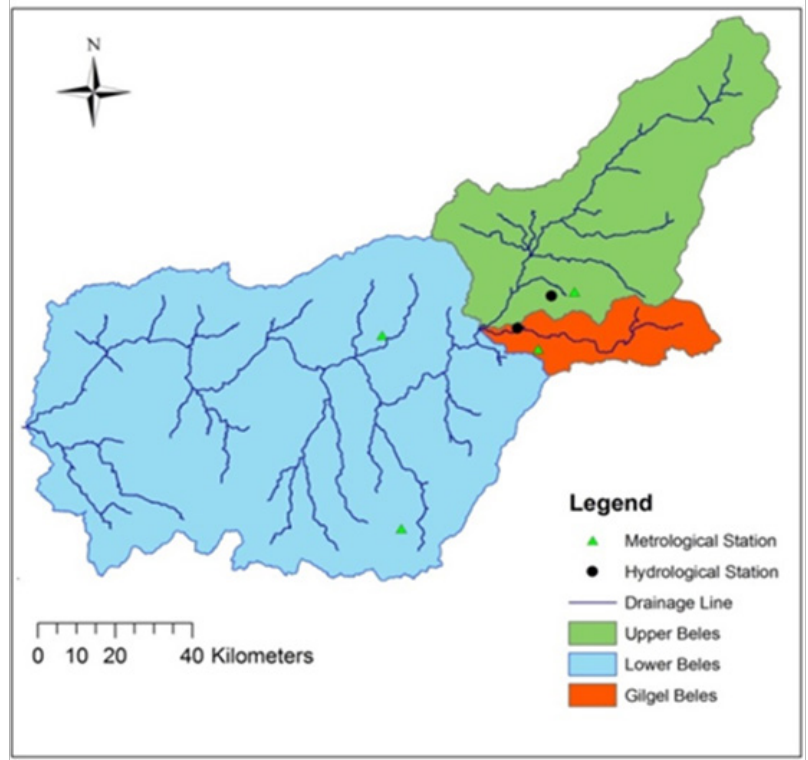

Figure 6 Map of sub-watershed.

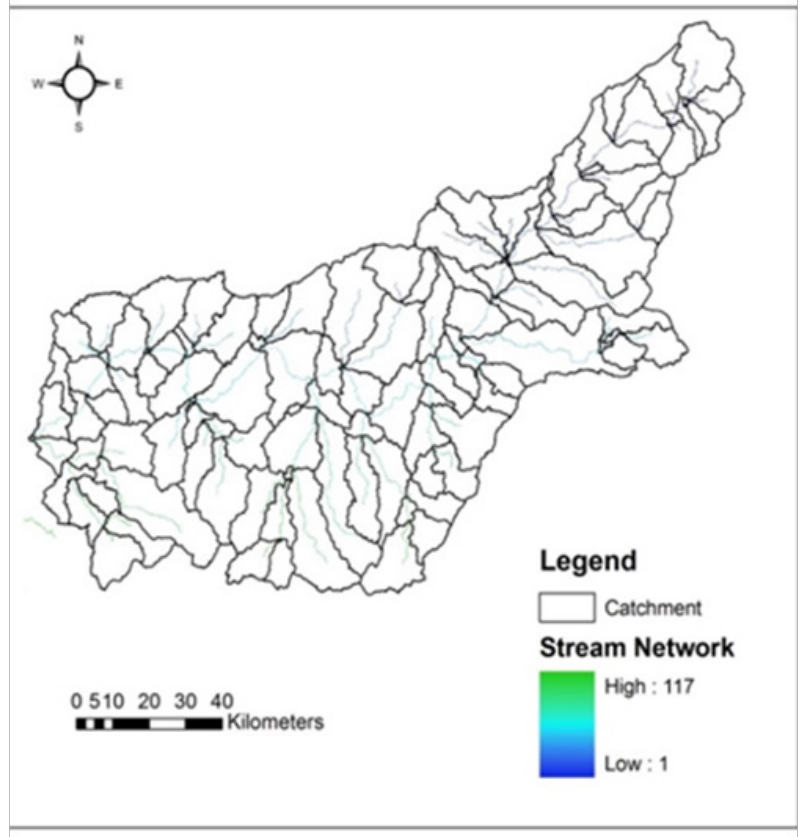

Figure 7 Terrain processing of Beles River.

\section{Surface runoff in beles river basin}

The result of model calibration and validation of daily surface runoff for Gilgel Beles sub basin from 2003-2005 showed that $\mathrm{RE}$ percentage of $-0.64 \mathrm{~mm}$ and $-0.23 \mathrm{~mm}$ respectively (Figure 8 ) suggesting that in both cases there is under prediction of simulated surface runoff. The result of simulated surface runoff is smaller in the lower Beles sub basin which may be due to the fact that the area up stream of the area receives the lowest annual precipitation (less than basin average) but more or less the discrepancy between measured and simulated values becomes smaller in most cases, probably because the assumption about the contribution from groundwater drainage is less considered in the model for the study area. And also the result showed that Relative Error for calibration and validation of simulated daily surface runoff $-0.66 \mathrm{~mm}$ and $+0.6 \mathrm{~mm}$ respectively indicating that under estimation for calibration but over estimation of validation in Upper Beles sub basin (Figure 9). Bennett et al. ${ }^{15}$ stated that the residual plot reveals un-modeled behavior when there is systematic divergence from zero. Hence; the reason for this divergence in both cases could be due to uncertainty in both the spatial accuracy and distribution of precipitation, the area coverage of the catchment, daily observed discharge measurements probably doesn't accurately capture peak runoff events and also there may be base flow under consideration of the model. Besides, Senay \& Verdin ${ }^{16}$ stated that in large watershed areas may result in over estimation of the runoff when the substantial transmission losses aren't considered. And also Halwatura \& Najim ${ }^{17}$ suggests that if there is a sudden heavy rainfall after two to three weeks dry spell, the model tends to over predict the run off. Daily rainfalls that are more than $40 \mathrm{~mm}$ receiving continuously more than one week also tend to over predict runoff.

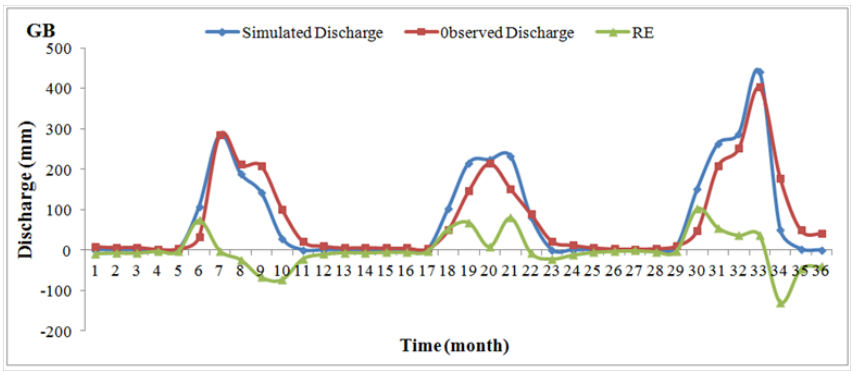

Figure 8 Gilgel Beles sub-basin model calibrated \& validated result evaluation.

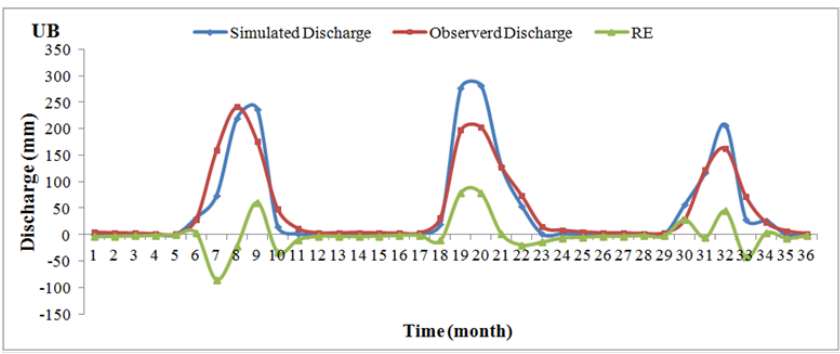

Figure 9 Upper Beles Sub-basin model calibrated \& validated result evaluation.

\section{Total loss in the beles river basin}

The result showed that HEC-HMS model take in to account loss as precipitation a loss which is mainly influenced by Evapotranspiration, plant interception and depression storage. For estimation of surface runoff the model uses total monthly Evapo-transpiration which may influence the result of surface runoff simulation. Hence, the simulation results of surface runoff from 2003 to 2005 show that the mean monthly loss values are higher during May to October and lower values are at September to January for each sub basin. The mean annual loss was $48 \%$ of total annual precipitation loss but in 2005 from total annual rainfall $55 \%$ was lost in Gilgel Beles. 29\% of mean loss was from total annual precipitation in Upper Beles but only $19 \%$ of mean loss was from total annual rainfall in Lower Beles but about $64 \%$ of mean annual runoff came from total annual rainfall 
in this sub basin. Form the result it can be conclude that the highest loss was from agricultural land, forest and settlement or urban areas since the urban areas are mainly impervious surface with lower losses.

\section{Water balance assessment of beles river basin}

Based on the assessment result of daily simulation of the hydrological components of the Beles River Basin from 2003 to 2005 for each sub basin, showed that losses exceed precipitation in most of months in the year of sub basin which makes a deficit year of soil moisture. The highest water deficit was found in the lower basin in 2003 and 2004 of Lower Beles which could support that increase precipitation and temperature drop with increasing the elevation besides the high temperature and vegetation cover type of the area results in high loss especially Evapo-transpiration. ${ }^{18}$ Therefore, the simulated result of water balance assessment summery showed that 2004 for Gilgel Beles and Upper Beles found to be a water surplus year were as 2003 showed the deficit year in the basin but 2005 was found almost balanced soil moisture storage in the River Basin. Based on the result of water balance assessment it can be concluded that there was variation of water availability from 2003 to 2005 and this assessment is done with the relative error of HEC-HMS model simulation and according to Gebreyohannes et al. ${ }^{19}$ suggested that this error could be subtracted from the runoff.

\section{Conclusion and recommendation}

From this study, comparison of observed and simulated river discharge at two gauging station in the basin showed that the model under predictions for Gilgel and over prediction for upper Beles but different literature showed it is reasonably accepted. Hence water balance assessment indicated that loss constitutes high percentage of total annual precipitation and it is mainly influenced by precipitation and potential Evapo-transpiration and to some extent soil type and vegetation cover. The monthly surface runoff from 2003 to 2005 in the Beles River Basin ranges from 0 to $440.2 \mathrm{~mm}$ (mean of 76 $\mathrm{mm}$ ) for Gilgel Beles, 0 to $281.1 \mathrm{~mm}$ (mean of $55.7 \mathrm{~mm}$ ) for upper Beles and 0 to $283.7 \mathrm{~mm}$ (mean of $42.4 \mathrm{~mm}$ ) for lower Beles. Bare land, cultivated land and urban land uses on sandy clay soil produced the highest surface runoff in the basin. According to water balance assessment, the highest water deficit was observed in 2003 and 2004 of Lower Beles but 2004 for Gilgel Beles and Upper Beles was found to be a water surplus year were as 2003 showed the deficit year. There is no significant change in soil moisture storage in Beles River Basin in 2005. From this study, it is recommended that water balance assessments have the ability to compare river discharged in the areas where there is limitation of measured data because it doesn't require lot of input data. Therefore, the hydrological findings and information generated on surface water balance assessment of this study can be used in planning of water resource management in Beles River Basin (Figure 10). Efficiency of the model may increase if the model application is done in seasonal basis or less like wet or dry season for this study area because there is erratic annual rainfall in the basin. Hence; in order to mitigate the especially social, economic and environmental challenges which may directly related to water issues and which could be a major limitations in the near future in Africa especially Ethiopia, it would be advisable to consider immerging issues in water resource measures like GIS modeling with Remote Sensing data for effective and efficient water resource management when there is limited and lack of data.

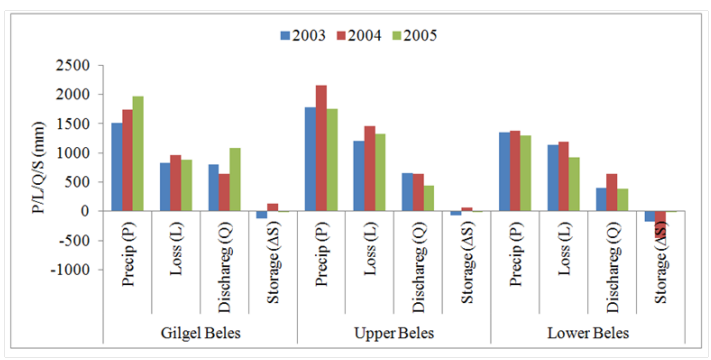

Figure I 0 Summary of water assessment in Beles River basin.

\section{Acknowledgements}

I would like to thank Ethiopian Institute of Agricultural Research (EIAR), National Metrology Agency (NMA) and Ministry of Water Resources of Ethiopia for providing secondary data and valuable information as requested and grateful thanks to Dr. Istvan and Dr. Vince for their comments and technical support.

\section{Conflict of interest}

Authors declare there is no conflict of interest in publishing the article

\section{References}

1. Gebremedhin G, Asfaw K. Irrigation in Ethiopia: A review. Aca $J$ of Agricultural Research. 2015;3(10):264-269.

2. FAO. Irrigation in Africa in Figures. FAO water report 29, Italy; 2010.

3. Ministry of Water Resources (MOWR). Water Resource Management Policy (WRMP). Addis Ababa University, Ethiopia. 2013.

4. World Bank. World Bank Development Indicator (WDI) report, USA; 2015.

5. Conway D. A water balance model of the Upper Blue Nile in Ethiopia. Hydro Sciences J Des Sciences Hydrologiques. 1997;42(2):265-286.

6. Diriba K, Sorteberg A. Characterizing the Predictability of Seasonal Climate in Ethiopia. University of Bergensis, Ethiopia. 2013. p. 1-280.

7. Jyrkama MI, Sykes JF. The impact of climate change on spatially varying groundwater recharge in the Grand River watershed (Ontario). $J$ of Hydrology. 2007;338(3-4):237-250.

8. Ashebir H. Characterization of Beles River Basin of Blue Nile Sub-basin in North-Western Ethiopia using Arc-Hydro tools in Arc-GIS. Int $J$ of Water Resources and Environmental Engineering. 2017;9(5):113-120.

9. Collick AS, Easton ZM, Adgo E, et al. Application of a physically-based water balance model on four watersheds throughout the upper Nile basin in Ethiopia. Aardvark Global Publishing, Ethiopia. 2008. p. 1-113.

10. Jasrotia AS, Abinash M, Sunil S. Water Balance Approach for Rainwater Harvestingusing Remote Sensing and GIS Techniques, Jammu Himalaya, India. Water Resource Management. 2009;23(14):3035-3055.

11. Thiemig V, Rojas R, Zambrano BM, et al. Validation of Satellite-Based Precipitation Products over Sparsely Gauged African River Basins. JHM. 2014;13(6):1760-1783

12. Rybak OO, Volodin EM. Applying the Energy-and Water Balance Model for Incorporation of the Cryospheric Component into a Climate Model. Part I. Description of the Model and Computed Climatic Field of Surface Air Temperature and Precipitation Rate. Russian Meteorology and Hydrology. 2015;40(11):731-740. 
13. IUSS Working Group WRB. World Reference Base for Soil Resources. World Soil Resources Reports No. 103, Italy; 2015. p. 1-145.

14. US Army Corps of Engineers (USACE). Hydrological Modeling System HEC-HMS. Hydrological Engineering Center, USA; 2010. p. 1-148.

15. Bennett ND, Croke BFW, Guariso G, et al. Characterizing Performance of Environmental Models. Environmental Modeling \& Software. 2013;40:1-20

16. Senay GB, Verdin JP. Developing maps for water-harvest potential in Africa. American Society of Agricultural Engineers. 2004;20(6):789-799.
17. Halwatura D, Najim, MMM. Application of the HEC-HMS model for runoff simulation in a tropical catchment. $J$ of Environmental Modeling \& Software. 2013;46:155-162.

18. Usmanov S, Yasuhiro M, Tetsuya K. Evaluation of Interpolation Methods for Spatial Modeling of Reference Evapo-transpiration Using Modified Hargreaves Equation. J of Arid land Studies. 2015;25(3):141-144.

19. Gebreyohannes T, Florimond D, Kristine W, et al. Application of a spatially distributed water balance model for assessing surface water and groundwater resources in the Geba basin, Tigray, Ethiopia. Journal of Hydrology. 2013;499:110-123. 